1978 Energy as it relates to the quality and style of life. Annual Review of Energy. (J.M. Hollander, M.K. Simmons and D.O. Woods, eds.), Palo Alto, California: Annual Reviews Press. Vol. 3, pp. 1-28.

Paine, Robert (ed.) 1985

Advocacy and Anthropology. Memorial University of Newfoundland. St. Johns: Institute of Social and Economic Research.

Ratcliffe, John ** 1978

Saberwal, Satish (ed.)

1968

Social justice and the demographic transition: lessons from India's Kerala state. International Journal of Health Services. 8(1): 123-144.

Academic colonialism: a symposium on the influences which destroy intellectual independence, Seminar (New Delhi), No. 112: December 1968.

Shah, Saubhagya

Srinivas, M.N.

1959

'Western bias behind failure of development projects.' The Rising Nepal. March 26, 1994: pp. 1 and 8.

The dominant caste in Rampura. American Anthropologist. 61:1-16.

Tamang, Davika, G.J. Gill and G.B. Thapa (eds.)

Indigeneous Management of Natural Resources in Nepal. Kathmandu: His Majesty's Govemment, Ministry of Agriculture, and Winrock International.

Tiwari, Rajiv

1987

Tehri: temple or tomb? Himal, Vol. 0, No. 0. May, 1987.

Windmiller, Marshall 1970

The Peace Corps and PaxAmericana. Washington, D.C.: Public Affairs Press.

\section{DEVELOPMENT ISSUES RAISED DURING THE "PEOPLE'S MOVEMENT" OF 1990 ${ }^{1}$}

\author{
Krishna B. Bhattachan
}

To get more insight into the relation of the "people's movement" to contemporary problems of underdevelopment in Nepal, it will be of great help to look at political pamphlets distributed by political parties and professional groups. In this paper I will show that many development issues were raised in the political pamphlets released by political parties and professional organizations. At the end, I will analyze the two dominant beliefs of the Nepalese public about the current situation of underdevelopment and future prospects of development of the country.

\section{Development Issues Raised in the Political Documents} Released by Major Political Parties

Political pamphlets played a very significant role in Nepal under the repressive reign of the autocratic partyless Panchayat regime. Political parties were banned in Nepal by the late King Mahendra in 1960; later by the 1962 Constitution. Political meetings, including mass meetings and street demonstrations against the partyless Panchayat system and the king, were outlawed. In the beginning of the "people's movement" many political leaders and political activists were imprisoned for "public security" reasons. Most of the national and local newspaper and newsmagazine were banned and many editors were imprisoned. All the international newspapers were confiscated at the entry ports. In such adverse circumstances, one effective way to break the barrier against spreading the messages of political parties was the wide circulation of political pamphlets, which are not expensive and easy to distribute. Itseffectiveness depends on how the people and public could relate their problems and demands to those mentioned in the pamphlets. If the pamphlets hit the right chord of the people's sentiment, they could help them to engage in public debate about matters of common concern. 
Political pamphlets were widely distributed by leading political parties, sometimes jointly and sometimes independently, at various stages of the united "people's movement." Among the parties distributing pamphlets were the Nepali Congress (NC) and the United Left Front (ULF) -- comprised of seven communist parties: Nepal Communist Party (Marxist), NCP (Marxist-Leninist), NCP (Chautho Mahadhibeshan), NCP (Manandhar), NCP (Varma), NCP (Amatya), and Nepal Majdoor Kisan Party (NMKP) (the "Nepal Worker and Peasant Party"). The United National People's Movement (UNPM), another coalition front of radical communists, was comprised of five parties and some leftist individuals: NCP (Masal), NCP (Mashal), Sarvahara Sramik Sangathan (SSS) (the "Proletarian Labor Organization"), Nepal Marxist-Leninist Party (NMLP), and the Sambhuram Shrestha group. The pamphlets are significant for various reasons: these documents reflect assessments of the current political and economic condition of the country; they contained demands for changing the current situation of underdevelopment of the country; they reflected popular aspirations as perceived by the political parties; and they were one of few available ways for the people to participate in political discussions.

The first political pamphlet was released by seven leftist political parties who joined in the ULF on January 14, 1990 in order to participate in the popular movement against the ruling Panchayat government. Press statements with the same contents were released separately by each of these seven parties of the newly-organized ULF (see Antarastriya Manch 1990:21-22; Jhilko 1990a: 49$51^{2}$ ). This document was about their points of agreement, which were minimal, but were the only basis for the newly-formed ULF. It contained three sections: the first consisted of 18 points containing demands regarding social, economic, and political issues; the second totalled eight points about the mechanics of working relationships of the ULF with other popular movement groups, especially the NC. The 18 points included in the first part of this document were later released as the demands of the ULF during the early stage of the movement.

Among the 18 points, some were political demands to end the partyless system and establish a multiparty system; lift the ban on all political parties, as well as independent class and professional organizations; reinstate fundamental human rights; eliminate all Kala Kanun (black law); ${ }^{3}$ release all political prisoners; stop all political atrocities and arrests made in different parts of the country; renew Nepal-India relations on the basis of Panch Shila $;{ }^{4}$ and follow a foreign policy strictly compatible with non-alignment. The main economic demands were strict control over skyrocketing prices; strict action against corruption, commissionocracy, smugglers, and black marketeers; daily availability of consumable commodities in all parts of the country without any discrimination; guaranteed work to everyone; increased wages and fixed minimum wages; the right to organize trade unions, elimination of dual ownership of land; decreased price of fertilizer; improved seed and insecticide; decreased interest rate; guaranteed farm profits; and increased salaries of employees in accordance with price increases, with the maximum increase for the lower-class employees. Finally, the social demands were guaranteed equal opportinity for developmen to all castes, ethnic and language groups and regions of the country, and affordable education for all people. At this point one may wonder whose wishes do these represent? The simple answer is, everyone's interests. These lists of demands, representing various classes and groups, were incorporated in political pamphlets to gain their sympathy, support, and participation to topple the partyless system. The leaders of the political parties who listed those demands knew that even if they came in power it will be difficult to fulfill them.

In their second political pamphlet, released as an appeal from the ULF, the 18 political, economic, and social demands were put forward after discussing in detail the problems facing the nation. This was basically an assessment of the continuing situation of underdeveloment and a demand for a radical transformation of society and economy through the transformation of the political system. The ULF, in its appeal, asserted that "with the extension of the partyless Panchaya system in Nepal, the country is heading downhill toward massive destruction" (see Antarastriya Manch 1990-1991:23).

The ULF further asserted that the imposition of the partyless system for about three decades had resulted in political, economic, social, and cultura anomie, killing multiparty democracy, depriving fundamental human rights of the people, taking away their right to express their pain through mass meeting and demonstrations, and torturing many activists who denounced the autocratic system (see Antarastriya Manch 1990-1991:23). The ULF, in its appeal, furthe alleged that the partyless Panchayat system had squeezed the economy by developing an externally dependent economy, fulfilling the interest of rulers and weal thy people, and encouraging corruption, black marketing, smuggling, and commissionocracy. On the other hand, the living standard of the majority of the people had fallen. Peasants, workers, national capitalists, and national businessmen were not able to see economic progress of the country. Communalism ${ }^{5}$ is on the rise. In brief, the ULF stated that "the country is in crisis not only in economic and political but all sectors. The increasing national aspiration is for radica change in the country...The progress of Nepali society is impossible as lon as such a system [Panchayat] exists. Therefore, today's first essential need is the 
end of the partyless Panchayat system and the establishment of a democratic multiparty system. This is today's national aspiration too" (see Antarastriya Manch 1990-1991:23).

The punch line of the ULF documents was the strong correlation between two variables: politics and development, with the former being an independent and the latter a dependent variable ${ }^{6}$. The ULF believed that partyless politics leads downhill to underdevelopment; a multiparty politics opens up the gate of development. Partyless politics blocks wider participation of the people in the country's development; party politics increases participation of people across the board.

Similar assessments about the current political economic condition of the country were made by the NC in its historic national convention held in Kathmandu, January 18-20, 1990. The political resolution passed by the NC contained seven points (see Antarastriya Manch 1990-1991:24-25; and Jhilko 1990b:52-53). The party resolution stated: "Today our country is being attacked by several problems at once. On the one hand, the country's economic condition is deteriorating every day, and on the other hand, foreign debt is rising." It further stated that Nepal has become the fourth poorest country in the world due to the wrong policies adopted by the Panchayat system. The Panchayat government failed to provide relief to the people from price increases after the trade and transit impasse with India. The country was drowned in the pool of corruption, ${ }^{7}$ bribery, commissionocracy, and addiction. ${ }^{8}$ The NC asserted that the only reason for such a miserable condition of the country is an undemocratic partyless Panchayat system introduced in 1960. The NC, like their allies the ULF, believed on the strong correlation between an independent variable "politics" and a dependent variable "development." All the wrongdoing during the last three decades was because of partyless politics that prohibited wider participation of the people. The party further believed that the door to development and people's participation would be opened by a multiparty system. The feeling of unity among various groups of people could be possible, the NC believed, only in a democracy, and national unity is a must for coming out of this crisis. The NC appealed for a nonviolent "popular movement" to begin February 18, 1990, the official annual "Democracy Day," for the establishment of complete multiparty democracy in the country.

In a joint appeal for a "people's movement" released on February 18, 1990 by the NC and the ULF, after both parties' endorsement of the document on February 9,1990, they appealed to the people to participate in the movement for the establishment of a multiparty democratic system in the country (cf. FOPHUR 1990:4-5; see also Antarastriya Manch 1990-1991:26). Both parties, in their appeal, alleged that the ruling Panchayat government had taken away people's political as well as human rights. They further stated, "The economic condition of the people is dreadful. Prices have skyrocketed. Unemployment has been a problem. The base of this system has been smuggling and corruption. The economic gap between a handful of persons and the rest of the people is growing. Ordinary people are finding it difficult to survive" (cf. FOPHUR 1990:4). Both parties believed, "Nepalese are speaking unanimously for change" and the "truth will prevail. And the truth is the power of the people." Both parties strongly believed that "change is certain."

The central argument of both the ULF and the NC was that change in politics was essential to change in economy and society. When they said that, the NC being a centrist party, and the ULF being dominated by liberal communist parties, they did not mean a "radical change" in the social structure through change in the political system, as suggested by some radical communist alliances, like the UNPM discussed below. Radical change was a stated long term goal of the ULF, but for some time they had accepted a multiparty political system, parliamentary form of government, and constitutional monarchy. Clearly, the position taken by the NC and the ULF was more "pro-reform" than "revolutionary."

The United National People's Movement (UNPM), the second coalition group that participated in the popular movement, also made a similar assessment of the political and economic condition of the country, but, in sharp contrast to the NC and the ULF, took a radical position by denouncing the Western parliamentary form of government which the moderate communist party alliance, the ULF, accepted. In its statement about the policies and programs released on February 12,1990, the UNPMextended its full support to the movement initiated by the NC and the ULF (see Antarastriya Manch 1990-1991:28-29; and Jhilko 1990:53-54).

The UNPM alleged that for the last three decades the ruling Panchayat government had not only taken away people's birthrights, but also "....... failed not only to solve any of the fundamental problems like democracy, nationalism, and people's livelihood, but also failed to make any efforts to solve them." Because of the failure of the Panchayat system, the UNPM noted that now the question confronting the nation was how to solve the fundamental problems of the people, which are nationalism, democracy, and livelihood. 
The fundamental problems to be solved by the new system, as identified by the UNPM, were to provide land to the peasants who comprised the majority of the total 18 million people of Nepal, because their problem is the country's fundamental problem and its solution is "land to the tillers"; to liberate women from political, social, and family oppression and exploitation and provide rights and opportunities equal to those of men; to end special rights and privileges for a single language and give equal status to all languages; and to void the unequal treaty made in 1950 with India and establish friendly relations with all countries on the basis of Panch Shila. The UNPM argued that the tasks of the new system would be to create an independent, self-reliant national economy by eliminating imperialist and expansionist control over our national economy; to guarantee people's freedom and rights; and to give supreme priority to the fulfillment of basic needs, including work, food, clothing, shelter, education, and health of workers, peasants, low income employees, students, intellectuals, small businessmen, and several other groups (see Antarastriya Manch 1990-1991:29; and Jhilko 1990a:54). The UNPM strongly believed that neither the partyless Panchayat system nor the Western parliamentary form of government as proposed by the NC, also supported by the ULF, could achieve those above mentioned fundamental goals. Therefore, the UNPM asserted that the fundamental problems of the people could be solved only by a "people's democracy" or "New Democracy" (see Antarastriya Manch 1990-1991:29).

The punch line of the radical communist group, the UNPM, was similar to that of the NC and the ULF to the extent that partyless politics was the main culprit of Nepal's underdevelopment, but it differed with them substantially by rejecting multiparty politics as its solution and strongly advocating a single party political system ruled by the Nepalese proletariate. Although UNPM differed with the NC and the ULF substantially, they all agreed on the point that "politics," in this case the partyless Panchayat system, was responsible for the crisis in the economy and the growth of internal problems. In other words, all parties believed that "politics" and "development" are closely related; the former precedes the latter. But the UNPM differed with others on the solution to this problem: the UNPM demanded the establishment of "people's democracy" or "New Democracy" and the NC and the ULF accepted a multiparty system with a parliamentary form of government and a constitutional monarchy. Those two different ideas were reflected in the pamphlets released by various professional groups during the progress of the movement.

\section{Development Issues Raised in the Pamphlets Released by Some Professional Groups}

Many professional groups, including teachers, lawyers, doctors, engineers, and pilots actively participated in the "people's movement" of 1990 . Their active support of the political movement against the partyless Panchayat system helped to take the movement beyond political parties.

During the early phase of the movement when the ruling Panchayat government began a crackdown on the movement leaders and activists, using excessive force and brutality to supress the movement, the professionals, who generally are less active in political life, began to show their concern for the nation's problems and extend support to the pro-democracy movement. Professional associations of doctors and engineers released separate statements strongly demanding that the government stop its brutality against the people and appealing to the people to participate in the movement to overthrow the Panchayat system. In both statements the central issue was the problem of the development of the country.

In its "Appeal to the Government and People of Nepal," issued on February 27, 1990, the Nepal Engineers Association (NEA), Kathmandu, states, "Every conscious Nepalese is now forced to think how various nations, especially those similar to ours in terms of development, have made tremendous progress for the last 31 years, i.e., since 1960." Further, "The entire conscious community knows pretty well that it has been, implicitly or explicitly, a matter of serious concern how the development process in the nation has suffered setbacks from the lack of short- and long-term planning based on national interests, how corruption, rampant in the financial and administrative machinery, has crippled the nation, and how its small technological sector has been abused, e.g., the mushroom growth of fake industries instead of setting up industries for fulfilling the nation's basic needs. The lack of explicit policy and the mismanagement of the development sector have thrust the nation to the second poorest status in the world, in spite of the flow of foreign loans and grant-in-aid" (see FOPHUR 1990:6).

Those impeccable observations and comments by the Nepalese engineers, whose total number is about 2,000 , should be well taken. They are one group of professionals who are actively engaged in the material development process, such as building highways and roads, bridges, dams, canals, hydroelectricity plants, tunnels, and buildings. However, the other side of the coin, ironically, is 
that they are part of the process of the mismanagement of scarce "development budget," and corruption. But it is precisely because of their two faces, they know better than others about the country's heartbeat of development.

The implication of the NEA Appeal is in conformity with various political parties, i.e., a firm belief that "politics" precedes "development." The NEA's indictment on "politics", particularly the partyless Panchayat, for blocking the process of development through corruption and mismanagement, left the question hanging, how these evils would go away by changing the political system from partyless to a multiparty system?

Similar concerns were shown by the Nepal Medical Association (NMA). In its statement issued on March 1, 1990, NMA begins, "Today, while the rest of the world is progressive at various stages of development, we Nepalese, in a situation to deal with different diseases afflicting our poor countrymen, have been shocked by the cruel govemment oppression of unarmed citizens who had launched a peaceful movement from the 18th of February 1990. Today, while there is a worldwide movement for change, the Nepalese government has been exposed by its brutal action against the peaceful people not only nationally but internationally as well" (see FOPHUR 1990:7). At the end of the Appeal, the NMA demands the end of government brutality and the search for peaceful political solutions to the current political problems in order to "construct a political environment in which overall development of the nation is possible" (see FOPHUR 1990:8). The NMA, was not as explicit as their fellow association the NEA, in linking the process of development with "politics." But they too saw the possibility of "development" of the country by changing the "political environment," referring to the change from the "partyless" to a "multiparty" politics. Thus the medical professionals' views on development were not different from those of engineers and politicians.

A pamphlet entited Sabadhan! Bandukle Muktiko Agraha Mardaina ("Caution! Guns Cannot Kill the Desire for Liberation"), the Bahudal Bauddik Mancha ("Multiparty Intellectual Forum") stated that during the reign of the autocratic Panchayat regime since 1960, "a handful of shrewd people have become richer while poor people became poorer." It further states that "corruption, bribery, smuggling, black-marketing and commissionocracy got encouragement. The nation's coffers are empty. The nation's properties are deposited in foreign banks by the Pancha autocrats. The nation is sinking. People are dying."

Another underground organization, the Nepalese Forum For Democracy
(NFD), released a political pamphlet entitled "The Present Condition of Nepal," $"$ in which the king and the palace were blamed for emptying the national coffers. "The unbridled ambition of the king and the queen has repeatedly emptied the state coffers. The sale of the royal palace, ${ }^{10}$ the Nagarjun palace, and the Pokhara mansion ${ }^{11}$ proved the fact beyond doubt" (NFD 1990:1). Furthermore, "the palace has a monopoly over the main economic resources like the Hotel Soaltee Yeti Travels, Tea-state (sic), etc. Thousands of hectares of land have been registered in the name of the king and the queen" (NFD 1990:3).

The NFD provides some statistics comparing two rupees (about eight U.S. cents) of daily per capita income of a common man in the hills against 100,000 U.S. dollars of daily travelling allowance abroad for the king. Due to these facts the Forum remarked that "the slogan of the Panchayat, of economic development, is pure hypocrisy because the king and the members of the royal family have never looked upon Nepal as a nation. The nation, they think, is their Jagir"1 2 (NFD 1990:3). The NFD alleged that "in the name of national development billions of dollars begged from foreign countries have been used for political centralism and at the moment the Nepalese are staggering under the heavy burden of loans of 59 billion rupees (about 50 million U.S. dollars)." This might be the crux of the problem and the real culprit was not so much corruption in general as the exploitation by the royal family. But it is for sure that Nepalese have a strong belief that corruption outweights any other factor.

In the above discussion it is clear that professionals like engineers, medical doctors, and intellectuals agreed with the political parties that "bad politics," i.e., the partyless system was responsible for the underdevelopment of the country; the only possibility left was to change the "partyless politics" into a "multiparty politics." Unlike the political parties, these professional organizations did not specifically suggest or advocate "democratic socialism," or "New Democracy."

\section{Main Issues of Public Debate}

From the discussion and analysis so far it is clear that many issues were raised during the movement period. However, there were some issues highlighted more than others. I will discuss and analyze the two central development issues debated extensively during that period. Other issues were overshadowed by these two central development issues: One, "politics" precedes "development", and two, the institution of monarchy as the main obstacle for the country's development. 


\section{The Issue of "Politics" Preceding "Development"}

During the movement period in Nepal, like in many other third world countries, the public strongly believed that "politics" determines the development of a country. The two questions Nepalese asked and answered themselves were: Why is our country poor, underdeveloped? How can we develop our country? Their answer for both was "politics." However, they made a distinction between "destructive politics," like that of the Panchayat, more recently, and of the Ranas before 1950, and "constructive politics," like that of the multiparty system of the West. "Destructive politics" leads the country's economy downhill. Nepalese had a strong feeling that "constructive politics," especially a parliamentary form of government, would not only stop further deterioration, but would be able to boost the economy, rising from its ashes. This was the sentiment of the dominant political parties and the majority of the Nepalese.

There was a minority of radical communists who did not believe any of these arguments. They believed that only "New democracy" under the dictatorship of the proletariate would solve the current problem of underdevelopment of the country. Their main argument was that change of the political system would not be enough to break the current state of underdevelopment of the country. Change from one political system to another, in this case, from the partyless Panchayat system to the multiparty political system, would not change the social structure of society and thus, would not solve the problems facing the people. Instead, they called for the radical transformation in the existing semi-feudal and feudal social structure. They believed that the institution of kingship perpetuates feudalism in the country; therefore, its total elimination is the first step towards such transformation. They further believed that the dominant parties, the NC and the NCP (ML), were helping to maintain the feudal structure in the country. For them, "constructive politics," as suggested by the dominant parties were "destructive," like that of the partyless Panchayat system.

During the movement period, political leaders and the public were so overwhelmed by a "solo mission" of destroying the partyless system that they often preferred to affirm, rather than doubt, their belief that multiparty system is associated with development. Perhaps the "revolutionary mood" of the Nepalese during the movement period was not appropriate for thinking in detail about what they desired.

It appears that the Nepalese were "radical and stone-hard" while dismissing the partyless system and demanding a "miraculous change" in the society and economy, but "soft" in using means to achieve it. The question still lingers: Are both compatible? If we carefully study the history of Nepal, many of the charges made against the partyless Panchayat system, such as corruption, sycophancy, misuse of power and authority, violation of human rights, lack of freedom of expression, palace politics, and poverty existed prior to the system. And these are going to remain in the changed political environment; and are highly likely to remain in the future as well, if some "miracle" does not happen. The public debate was not so much about changing "the rules of the game," as about "changing the face" of the political system.

What I infer from this public debate about the precedence of "politics" over "development" is simply a desperate desire of the Nepalese to get out of the trap of continuing underdevelopment. Freedom of expression and respect for human rights are the beginning of a long journey toward "development." There remain, however, many things to be done beyond that point. A multiparty political system or a parliamentary form of government does not automatically bring "development." If it were that easy then all the third world countries could simply change their political systems and immediately get rid of their underdevelopment, living happily ever after in the "never, never land" of "development". Will this dream come true in Nepal?

\section{Role of the Monarchy:}

From Absolute to Constitutional Versus Its Elimination

Another hot topic of public debate during the later period of the movement was the role of the monarchy and its bearing on the development of Nepal. During the 30 years of the partyless Panchayat regime, the king was equated with the Panchayat and vice versa; ${ }^{13}$ the Panchayat projected the image of the king as a "benevolent monarch," who was a "development lover." Constitutionally, he was above the law because sovereignty was vested on him; and traditionally, he was the incarnation of the Lord Bishnu, the God of Procreation and Protection. Therefore, comments and criticism against the king and the Panchayat system were taboo. Violators had to pay a heavy price, often of their heads. But, the "people's movement" broke the taboo. The king, queen, and other royal family members came under public scrutiny.

The king and his palace was blamed for many wrongdoings. Many Nepalese believed that the palace had become a center of corruption. In cartoons and posters the king and the queen were ridiculed. In one cartoon, the king's lips were locked by the queen. Similarly, in a poster entitled "Bahudal Ajako Khancho IIo" 
("Multiparty is today's necessity"), the king was quoted as saying, "The end of partyless is today's necessity. This is the opinion of all the Nepalese. I also think so, but my queen does not accept."1 4

A magazine entitled Bhandaphor ("Expose") was published underground by the Samajik Bastabikata Udghatan Sanstha ${ }^{15}$ (SBUS) in March 1990. It was widely distributed and read by many people. In its editorial, the SBUS stated, "The king and the royal family members are pushing the country into a disaster by engaging in massive exploitation, supression and crimes. But there is no place to speak against their crimes, to write about those realities. Instead, those criminals are praised as the 'leaders of the nation', 'symbols of nationalism', 'centers of national unity', 'carriers of national development', 'people-lovers', and 'democrats' " (SBUS 1990:1). The SBUS (1990:1) further suggested that there are many hidden facts about the crimes committed by royal family members whose exposure will help to "think about whether it is possible or not to reform the miserable condition of people's livelihood, advance of the nation under the autocratic monarchy; if not, then what should be done?" The main implication of this question was that the "absolute monarchy" in the garb of "benevolent dictatorship" was the main culprit for the underdevelopment of the country; therefore, the possibility of development exists only in its elimination.

Ths SBUS (1990:6-9) appealed to the people to identify the root cause of the country's ailment. It believed that the people should get rid of the illusion that "the king is good, a development-lover, but all kinds of wrongdoers are the ministers and government employees." Here it should be noted that the ministers and government employees were also equally responsible for those wrongdoings. All of them were partners, not just the leader and followers. The SBUS (1990:6) pointed out that "the root and the main cause of Nepal's backwardness, poverty, exploitation, oppression, foreigner's brokerage, smuggling, commissionocracy, corruption, and brutality is the king and the monarchy.

The SBUS (1990:11) suggested a very radical solution to solve these chronic problems, "Now everyone should think, if we wants to destroy the partyless autocracy, commissionocracy, smuggling, etc., we should destroy the monarchy. Otherwise there is no sense in opposing commissionocracy and autocracy. In such situation, why should we not dare to destroy the monarchy which has been a communicator, organizer and protector of all this social garbage?"

The punch line of the SBUS was that "politics" and "developinent" are strongly related, but in the case of Nepal, "politics", particularly "destructive politics" in the form of partyless Panchayat system had been growing under the patronage of the monarchy; therefore, elimination of the institution of the monarchy is crucial to eliminate other chronic problems, including the partyless Panchayat system. The SBUS suggested that the gateway to the country's "development" would be opened up if the institution of the monarchy is destroyed; otherwise, the country's situation of underdevelopment would worsen in the future.

The SBUS provided many facts of wrongdoing by the royal family members, including the king and queen, during the past. Among this information, was the existence of the private property of the pseudonymous "Pamfa Devi", who, the SBUS suspected, was the queen. The SBUS (1990:26) stated, "As known from a palace source, about 350 million U.S. dollars (about 8,000 million Nepalese rupees) is in two bank accounts in Switzerland in the name of Pamfa Devi Thakurani. The same woman has bought 1700 hectares of land on an island in Greece. A huge amount of money has been deposited in British banks. In addition, it has been learned that bank accounts exist in other countries as well. It is being investigated." The SBUS asked, "Who would be that daring woman other than the country's 'only women leader', 'rajmahishi' ("royal lady"), 'universal mother', 'affectionate', 'people-lover', the Queen Aishwarya." People believed these claims, even if they were not accurate or were rumors, because the common people never benefitted from the huge amount of foreign aid that used to evaporate very soon from the nation's coffers and also because the common people were familiar with the level of corruption in public life. These claims substantiated their prior suspicions.

The extent of public debate on the role of the monarchy in the continuing underdevelopment of Nepal and the people's hope of getting rid of them crossed the Nepalese borders. The significance of this debate could be understood by the importance given by the international media. Some of this information was printed in many Western newspapers. In the San Francisco Chronicle (May 2, 1990:z6-3), Dan Spitzer wrote: " ..... King Birendra is one of the richest men in Asia. He owns an island in the Indian Ocean, extensive real estate in Scandinavia, buys gold confiscated from smugglers by his own government for little money, and recently sold much of his extensive royal properties to the government for a goodly sum while nonetheless keeping full use of them."

Similarly, Steve Coll reported in The Washington Post (February 25, 1990:A 23): "As the govemment confronts a growing and sometimes violent democracy movement in this Himalayan kingdom, Nepal's monarchy faces widespread 
perception among citizenry that King Birendra and his loyalists are getting richer while the country's peasants stay poor."

In the News India (May 25, 1990:22) published from New York, Rajendra Bajpai of Reuters reported that "rumors about the wealth and influence of Queen Aishwarya Rajya Laxmi Devi Shah, dubbed 'Mrs Ten.Percent' for her alleged Aishwarya Rajya Laxmi Devi Shah, dubbed the royal palace has ben forced publicly to deny them" and "underground publications paint her as a Mrs Ten percent who collects commissions of major business deals and is the power behind the throne- a sort of Imelda Marcos of Nepal." Bajpai further reported, quoting a Western diplomat, " I personally suspect what we hear about the queen is just rumors and slander', he said, 'I am not saying she is a lady sitting at home and knituing socks but I am highly skeptical that she plays the kind of role (attributed to her).' "

Radical communists, arguing from many of the allegations discussed above, demanded the abolition of the institution of the monarchy forever. They argued that this would help to end the feudal system in the country, to transfer sovereignty to the people in the real sense of the term, and to establish a people's republic.

But the demand of the minority radical communists was not accepted by the dominant political parties, especially the NC and the NCP (ML). Both agreed that the role of the king in the politics of Nepal should be limited to ceremonial functions in a constitutional monarchy. Some radical communist leaders suspect that their demands were used by those two dominant parties as bargaining chips to negotiate with the king and terminate the movement.

\section{NOTES}

1. This paper is modified version of a section of Chapter-III of my Ph.D. dissertation entitled "Public Debate on Development: Sociological Perspectives on the Public Philosophy of the Development of Nepal" submitted in the Graduate Division of The University of California at Berkeley on April 16, 1993 (Ann Arbor, Michigan : UMI Dissertation Service, Order No. 9407886).

2. Individual pamphlets are hard to find, but these were reprinted in these two Nepalese magazine, which are easily accessible in the libraries. Therefore, I will refer to these magazines, instead of actual pamphlets.
3. The Nepalese, who are opposed to the establishment, call "black laws" to those laws which are against their interests and violate basic human rights. In Nepal, black symbolizes something bad, evil, and sad. The "public security" law was one of these "black laws". This law was misused extensively by the ruling Panchas to imprison opposition political leaders and followers for years and years without any due proces of law through the courts.

4. Panch Shila is the five principles of peace: peaceful coexistence, nonaggression, noninterference in internal affairs of other countries, respect for other countries' sovereignty and territorial integrity, and equality.

5. Communalism, Sampradayik in Nepali and Hindi, is a widely used term in South Asia to refer to violent religious and racial tension among various groups, such as Hindu-Muslim in India, and Tamil-Sinhalese in Sri Lanka. In Nepal, the racial, religious, and regional tensions between the Hindus and non-Hindus, Tagadhari ("twice-born castes") and Matawali ("liquor drinking castes"), and Pahadiya ("hill people") and Madhesiya ("Terai people") are slowly on the rise. Until now, many political leaders have claimed that Nepali society has been characterized by racial/ethnic/ communal, religious, and regional harmony. But they forget that such harmony existed because of coercion, constitutional and legal as well as cultural, rather than being natural and spontaneous.

6. Such a correlation was derived politically, not statistically.

7. Perhaps corruption is one of the most talked about things in public by the Nepalese. If we look at the recent history of Nepal, i.e. after the "revolution of 1950", most of the politicians and other public figures have been charged with one or another kind of corruption. It has been a big issue during the past and present elections. Some opine that it is a necessary evil; others say it is an unfailing weapon to ruin somebody's public life; and still others arguc it should be stopped at any cost. Whether one likes it or not it is sure corruption will be one of the most debated issues in Nepal in the future.

8. During the Panchayat period some of the most talked about addictions of the Nepalese were related to alcohol, gambling, and drugs.

9. This pamphlet was published in Nepali and English languages. The English version seems to be a summary of the Nepali edition to reach the

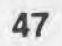


international audience. This pamphlet was widely distributed in the towns and villages alike. This document contained factual information as well as rumors. The power of this document lay in the fact that it allowed the common people to engage in public debate scrutinizing the institution of the king, one of the two tabooed fields for such debate; the other being the partyless system itself.

10. King Mahendra had sold the Narayan Hiti royal palace to His Majesty's Government. This palace is in the capital city Kathmandu and the king and other royal family live in this palace.

11. King Birendra sold these two palaces to His Majesty's Govemment.

12. Prior to 1950 , Jagir was a form of land tenure system in which the civil servants, military and police personnel get lands instead of monthly salary in lieu of their exceptional loyalty and service to the Rana rulers.

13. Many Nepalese intellectuals wondered why the king had been taking the side of the Panchas and not of the Nepalese during the Panchayat regime. They believed that he is the king of all the Nepalese, not of the Panchas only. They also wondered what the king would do if the Panchayat system was overthrown by the people.

14. See the photograph of this wall poster in Bonk 1990:28.

15. The literal translation is "Social Reality Expose Institution."

\section{REFERENCES}

Antarastriya Manch 1990

Rastriya Jana Andolan 2046 ko Ghatana Kram ra Rajnaitik Dastabejharu ("Chronological Events of the National People's Movement 1990 and Political Documents"). Antarastriya Manch ("International Forum"), Volume 6, Number 52, pp. 21-30.

1990-91
Nepal Adhirajyako Sambidhan -2047 ra Sambidhan Sujhab Ayog ("The Constitution of the" Kingdom of Nepal and the Constitution Recommendations Commission-1990"). Supplement Edition.
Bonk, Thomas (Ed.)

1991

NEPAL: Struggle for Democracy. Documentation of the Recent Political History of the Kingdom of Nepal in Text and Photos. Bangkok: Media Imprinta.

FOPHUR

Jhilko

1990 a

$1990 \mathrm{~b}$

Nepalese

1990

Samajik

1990
FOPHUR \& Pro-democracy Movement. Kathmandu: Forum for Protection of Human Rights (FOPHUR).

News Letter. Kathmandu: FOPHUR.

"Janaandolankalin Dastabejharu" ("Documents of the People's Movement"). Jhilko, Vol. 11, No. 14, April-September, People's Movement Special, pp. 49-57.

"Antarbarta" ("Interview"), Jhilko, Vol. 11, No. 14, April-September, People's Movement 1990 Special, pp. 58-77.

Forum For Democracy (NPM) ("Nepali Prajatantrik Manch")

"The Present Condition of Nepal."

Bastabikata udghatan Sanstha (SBUS)

"Bhandaphor" ("Expose"). Kathmandu: SBUS. 